\title{
Interrelationships in community structure between shallow-water marine meiofauna and macrofauna in relation to dredgings disposal
}

\author{
P. J. Somerfield ${ }^{1, *}$, H. L. Rees ${ }^{2}$, R. M. Warwick ${ }^{1}$ \\ 1 Plymouth Marine Laboratory, Prospect Place, The Hoe, Plymouth PL1 3DH, United Kingdom \\ ${ }^{2}$ MAFF Fisheries Laboratory, Remembrance Avenue, Burnham-on-Crouch, Essex CM0 8HA, United Kingdom
}

\begin{abstract}
Patterns in community structure of macrofauna (Day grab samples), nematodes (Craib core samples and subsamples from Day grabs) and copepods (Craib core samples) along a transect through a dredgings disposal site in Liverpool Bay, UK, are compared, and related to a range of environmental measurements. Disposal of dredged material at the site has different effects on different components of the benthos. Nematodes are more sensitive to sediment structure and the ongoing disposal of dredgings at the site, but the method used to sample them influences the perceived pattern of impact. Subsampling from grabs is not found to be an adequate method of sampling meiofauna in studies designed to examine details of changes in community structure, although such samples may be sufficient for detecting that substantial changes have occurred. Macrofauna are more sensitive to concentrations of metals and longer term events at the site.
\end{abstract}

KEY WORDS: Meiofauna - Macrofauna - Nematodes · Community structure - Dredgings - Sampling

\section{INTRODUCTION}

Meiofauna have evoked considerable interest as potential indicators of anthropogenic perturbation in aquatic ecosystems (see review by Coull \& Chandler 1992) as they have several potential advantages over macrofauna, which have traditionally been the component of the benthos examined in pollution monitoring surveys. These include their small size and high densities, so that smaller samples may be collected, shorter generation times and no planktonic phase in their life-cycles, suggesting a potentially shorter response time and higher sensitivity to pollution (Heip et al. 1988, Warwick 1993). Although the responses of different groups of organisms to certain types of perturbation might be expected to differ, there are few studies in which the impact of anthropogenic disturbance on more than one component of the biota has been examined directly.

The 'New Site Z' dredgings disposal site in Liverpool Bay, UK, has received approximately 2 to $3 \mathrm{Mt}$ of mud

•E-mail: pjso@pml.ac.uk and sand annually since 1982, arising from the continuous dredging of navigational channels in the Mersey estuary and its approaches. The disposal site is dispersive as it is shallow $(10 \mathrm{~m})$, exposed to wave action from the west to the north, and tidal currents of up to $0.8 \mathrm{~m} \mathrm{~s}^{-1}$ occur in the vicinity. Previous surveys (Rowlatt et al. 1986, Rees et al. 1992) indicate a marked change in macrofauna community structure in the vicinity of the disposal site. The present study has 3 objectives: (1) to compare changes in meiofauna and macrofauna community structure in the vicinity of the disposal site; (2) to assess the utility of meiofauna samples collected by taking subsamples from grab samples in comparison with samples collected with a deliberate corer (Craib corer); (3) to relate the observed changes to measured environmental variables.

\section{MATERIALS AND METHODS}

Sampling design. Samples were collected along a transect running approximately north-south through the Liverpool Bay 'New Site Z' dredgings disposal site 


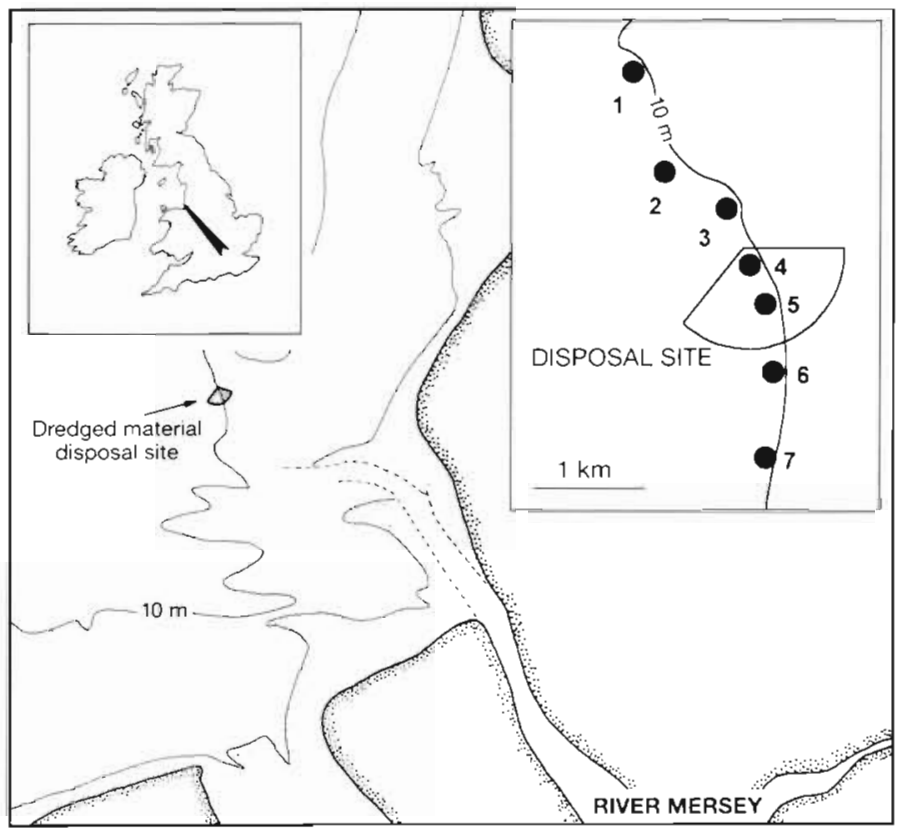

Fig. 1. Location of the 'New Site Z' dredgings disposal site in Liverpool Bay, UK, and (large inset) of the sampling stations in relation to the disposal site and the $10 \mathrm{~m}$ depth contour

(Fig. 1) on a MAFF cruise on board the RV 'Prince Madog' in September 1991. The transect followed the $10 \mathrm{~m}$ contour in order to minimise the effects of changes in depth in the consequent analyses. At each station 4 Day grab samples for macrofauna, 4 subsamples from Day grab samples $(50 \mathrm{ml}$ syringe to a depth of $5 \mathrm{~cm}$ ) and 4 Craib core samples for meiofauna were collected. Meiofaunal samples were immediately fixed in $4 \%$ buffered formalin. Macrofauna samples were sieved on a $1 \mathrm{~mm}$ mesh prior to fixation in $4 \%$ buffered formalin. Surficial sediment for analyses of metal concentrations, \% silt/clay and $\%$ organics were collected from a fifth Day grab sample at each station and frozen at $-20^{\circ} \mathrm{C}$ pending analysis.

Sample processing. Samples for meiofauna were washed on a $63 \mu \mathrm{m}$ sieve to remove formalin and most of the silt/clay sediment fraction. The meiofauna were then extracted using elutriation in fresh water and decantion through a $63 \mu \mathrm{m}$ sieve followed by a flotation extraction using a colloidal silica solution (Ludox TM from DuPont) with a specific gravity of 1.15. Meiofaunal communities in shallow sublittoral sediments are generally dominated by nematodes and copepods. Our analyses, therefore, are confined to these 2 taxa. Each sample was washed into a lined petri dish and the copepods picked out under a binocular microscope and identified to species using a compound microscope with Nomarski interference contrast illumination. The remaining sample was then slowly evaporated to anhydrous glycerol, evenly spread on microscope slides and the coverslips ringed with Bioseal. Nematodes were counted and the first 200 specimens encountered in each sample identified to species using a compound microscope with conventional bright-field illumination, allowing the total numbers of each species in each sample to be estimated. Macrofauna were identified to species level using standard taxonomic keys.

The \% silt/clay in sediment samples was determined by wet sieving using a $63 \mu \mathrm{m}$ sieve to separate the coarse and fine fractions which were then dried at $95^{\circ} \mathrm{C}$ and weighed. For the determination of metal concentrations the fine fraction was digested with aqua regia and analysed using flame atomic absorption spectrophotometry. The \% organic carbon and nitrogen in whole sediment subsamples were determined using a Perkin Elmer $240 \mathrm{CHN}$ analyser, after removal of carbonates by treatment with $8 \% \mathrm{HSO}_{3}$.

\section{DATA ANALYSES}

Copepods were absent from several of the subsamples from Day grabs, so analyses of the meiofauna sampled in this way are limited to the nematodes. The majority of the techniques used are described in Clarke \& Warwick (1994b)

Univariate measures of community structure. Univariate measures included: total abundance $(A)$, number of species (S), Shannon-Wiener diversity indices calculated using natural logarithms $\left(H^{\prime}\right)$, species richness (Margalef's $d$ ) and evenness (Pielou's J). $A$ and $S$ were converted to approximate normality using a $\log (1+N)$ transformation and the significance of differences between stations was tested using 1-way ANOVA.

Multivariate analyses of community structure. Nonparametric multivariate techniques were used, as discussed by Clarke (1993). Lower triangular similarity matrices were constructed using a range of data transformations and the Bray-Curtis similarity measure. Transformations were used to reduce contributions to similarity by abundant species, and therefore to increase the importance of the less abundant species in the analyses. Nematodes and macrofauna vary in abundance between single individuals and thousands of specimens within samples, so a fourth-root transformation was applied. Copepods vary between single specimens and hundreds of specimens, so a squareroot transformation was used. Ordination was by nonmetric multidimensional scaling (MDS) (Kruskal \& Wish 1978, Clarke \& Green 1988). Formal significance tests for differences between stations were per- 
formed using the ANOSIM permutation test (Clarke \& Green 1988, Clarke 1993). The species contributing to dissimilarities between stations were investigated using the similarities percentages procedure (SIMPER) (Clarke 1993)

It is important to obtain information on replicate variability at each station in order to establish unequivocally that there are community differences between them, amenable to interpretation. However, averaging samples then reduces the variability at each station. thereby increasing the signal-to-noise ratio in displaying patterns of change across sites, for example in relation to an environmental gradient. For this reason abundances from each station were averaged and similarity matrices constructed, which were then compared by means of a procedure used by Clarke \& Warwick (1994a) to examine community patterns for evidence of common biotic structure, and by Clarke et al. (1993) to measure the degree to which community change conforms to a linear sequence in a study of disturbance in coral communities. A Spearman rank correlation $(\rho)$ was computed between the corresponding elements of each pair of matrices, and the significance of the correlation determined using a permutation procedure.

Environmental variables. Environmental variables were converted to approximate normality using a $\log (1+N)$ transformation and ordinated using a correlation-based principal components analysis (PCA). A lower triangular Euclidean distance matrix relating to the ordination was constructed (Clarke \& Green 1988). For the reasons outlined above, and because only 1 sample for the analyses of environmental variables was taken from each station, the species abundances from the 4 replicates at each station were averaged for analyses linking biotic and abiotic data. These BrayCurtis similarity matrices derived from averaged transformed biotic data were compared with the environmental distance matrix using the procedure outlined above. The relationships between multivariate community structure and combinations of environmental variables were examined using the BIO-ENV procedure (Clarke \& Ainsworth 1993) which calculates rank correlations between a similarity matrix derived from biotic data and matrices derived from various subsets of environmental variables, thereby defining suites of variables which 'best explain' the biotic structure.

\section{RESULTS}

\section{Univariate measures of community structure}

Variation in nematode abundance in Craib core samples is not significant along the transect but the variation in other measures such as evenness $(J)$, richness $(d)$, diversity $\left(H^{\prime}\right)$ and species abundance $(S)$ is highly significant (Fig. 2, Table 1), lower values of all measures being found within the disposal site (Stns 4 and 5). Univariate measures derived from comparable grab subsamples (Fig. 3) are relatively insensitive. Only abundance $(A), S$ and $d$ vary significantly (Table 1), being lowest at $\operatorname{Stn} 5$, and the pattern of impact is not as clear as that indicated by univariate measures derived from Craib core samples.

Measures derived from the copepod data do not reveal a clear pattern (Fig. 4). While $J$ does not vary significantly between stations, other measures do (Table 1), but it is unclear what this variation indicates, a possibility being that the effect of dredgings disposal is to elevate values around the margins of the disposal site (Stns 2, 3 and 6). All univariate measures derived from macrofauna data vary significantly along the transect (Table 1), most being reduced at Stn 4 and to a lesser extent at $\operatorname{Stn} 5$, with the exception of $A$, which is

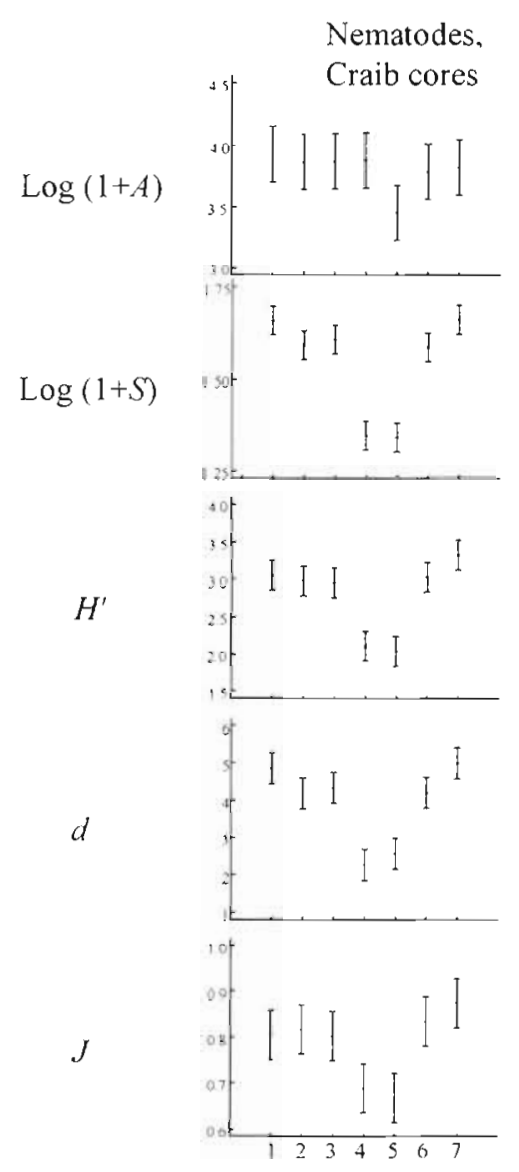

Fig. 2. Means and 95\% pooled confidence intervals for univariate measures of nematode community structure: transformed abundance $[\log (1+A)]$, transformed number of species $[\log (1+S)]$. Shannon-Wiener diversity $\left(H^{\prime}\right)$, Margalef's $d$ and Pielou's $J$ in Craib core samples from Stns 1 to 7 
Table 1 F-ratios and significance levels (from $F_{6,22}$ ) from 1 -way ANOVA tests for differences in various univariate measures of community structure (see text) between stations

\begin{tabular}{|c|c|c|c|c|c|c|c|c|}
\hline \multirow{2}{*}{$\begin{array}{l}\text { Univariate } \\
\text { measure }\end{array}$} & \multicolumn{2}{|c|}{ Nematodes (Craibs) } & \multicolumn{2}{|c|}{ Nematodes (grabs) } & \multicolumn{2}{|c|}{ Copepods (Craibs) } & \multicolumn{2}{|c|}{ Macrofauna } \\
\hline & $F$ & $\mathrm{p}$ & $F$ & $p$ & $F$ & $p$ & $F$ & $p$ \\
\hline $\log (1+A)$ & 2.2 & 0.08 & 10.6 & $<0.01$ & 6.1 & $<0.01$ & 11.8 & $<0.01$ \\
\hline $\log (1+S)$ & 54.7 & $<0.01$ & 12.4 & $<0.01$ & 5.8 & $<0.01$ & 17.2 & $<0.01$ \\
\hline$H^{\prime}$ & 27.1 & $<0.01$ & 1.5 & 0.24 & 3.7 & 0.01 & 25.4 & $<0.01$ \\
\hline$d$ & 29.1 & $<0.01$ & 3.5 & 0.02 & 3.6 & 0.01 & 31.3 & $<0.01$ \\
\hline$J$ & 8.9 & $<0.01$ & 1.1 & 0.42 & 1.4 & 0.25 & 15.5 & $<0.01$ \\
\hline
\end{tabular}

highest at Stn 4 (Fig. 5). Stn 1 also appears to have elevated numbers and decreases in other measures.

\section{Multivariate analyses of community structure}

MDS ordination (Fig. 6) of fouth-root transformed nematode data from Craib core samples clearly shows that the communities at Stns 4 and 5, within the disposal site, cluster separately from Stns 1, 2, 3 and 7, and samples from Stn 6 occupy an intermediate position. The ANOSIM significance tests for differences between stations indicate that all are significantly different ( $p<0.03$ ), except 2 and 3, and 4 and 5 (Table 2). For nematode abundance data from subsamples from Day grabs the major impact appears to occur at Stn 5

Nematodes,

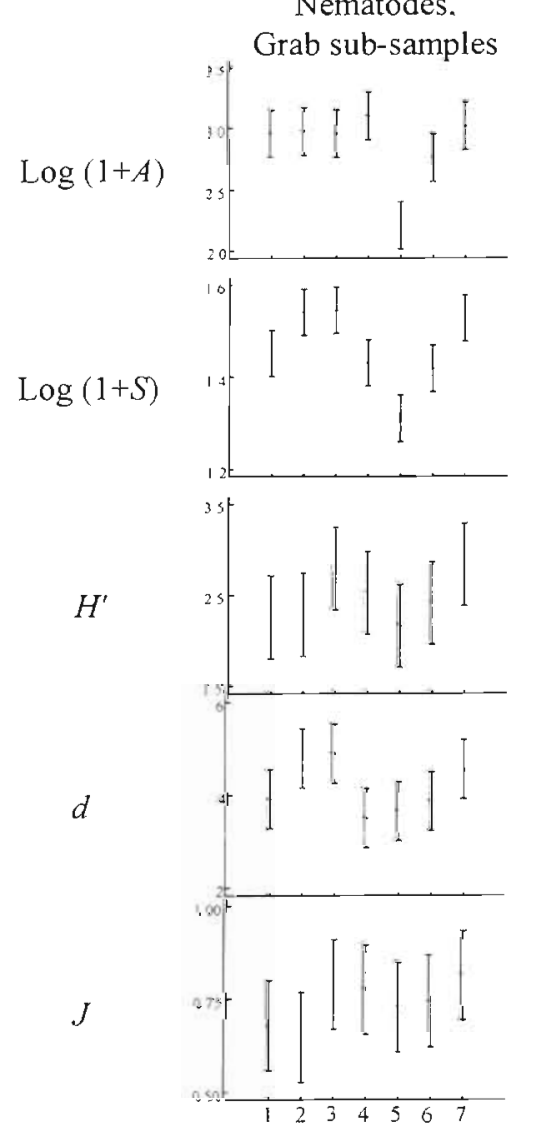

Fig. 3. Means and $95 \%$ pooled confidence intervals for univariate measures, as in Fig. 2, of nematode community structure in subsamples from Day grab samples from Stns 1 to 7

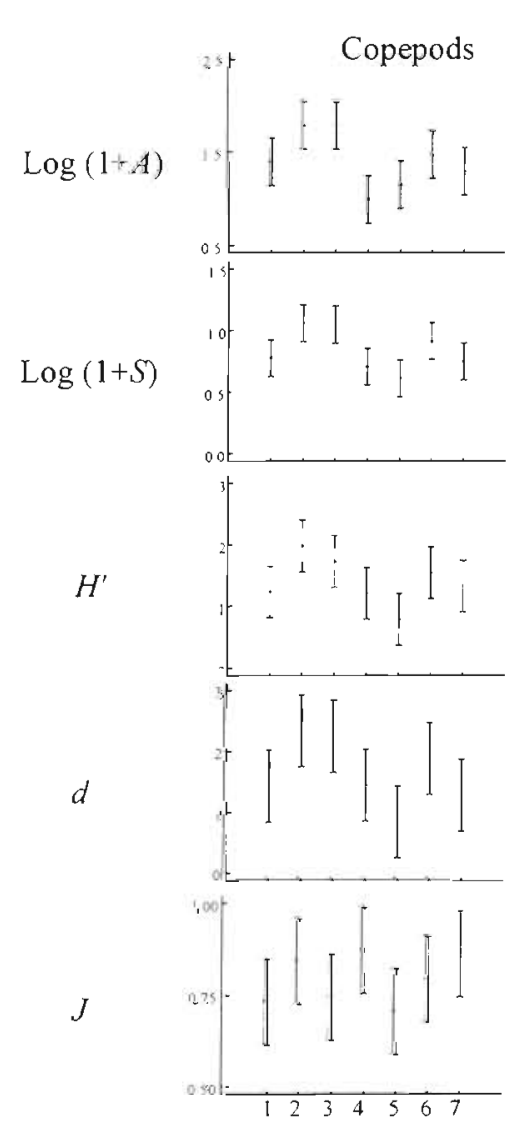

Fig. 4. Means and $95 \%$ pooled confidence intervals for univariate measures, as in Fig. 2, of copepod community structure, in Craib core samples from Stns 1 to 7

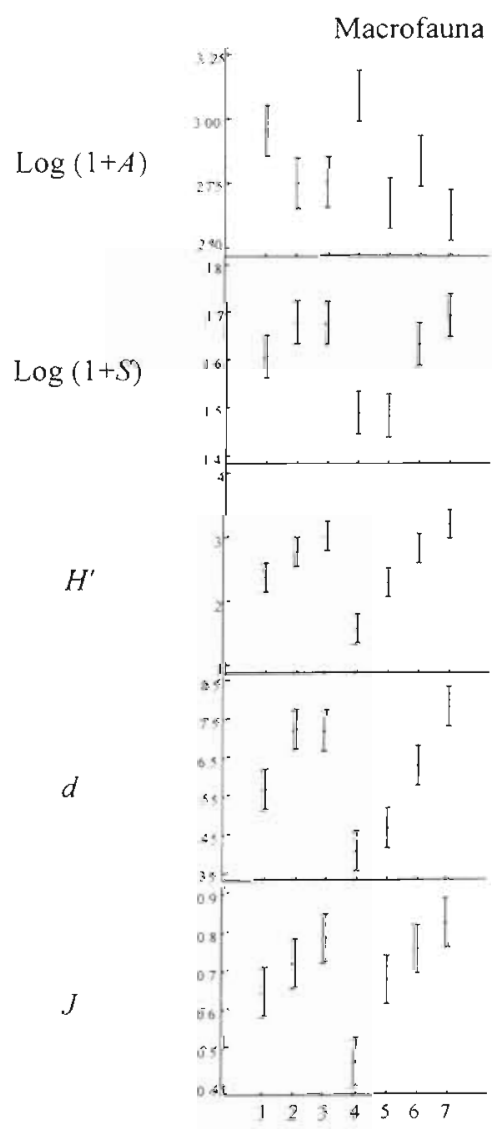

Fig. 5. Means and $95 \%$ pooled confidence intervals for univariate measures, as in Fig. 2, of macrofauna community structure in Day grab samples from Stns 1 to 7 

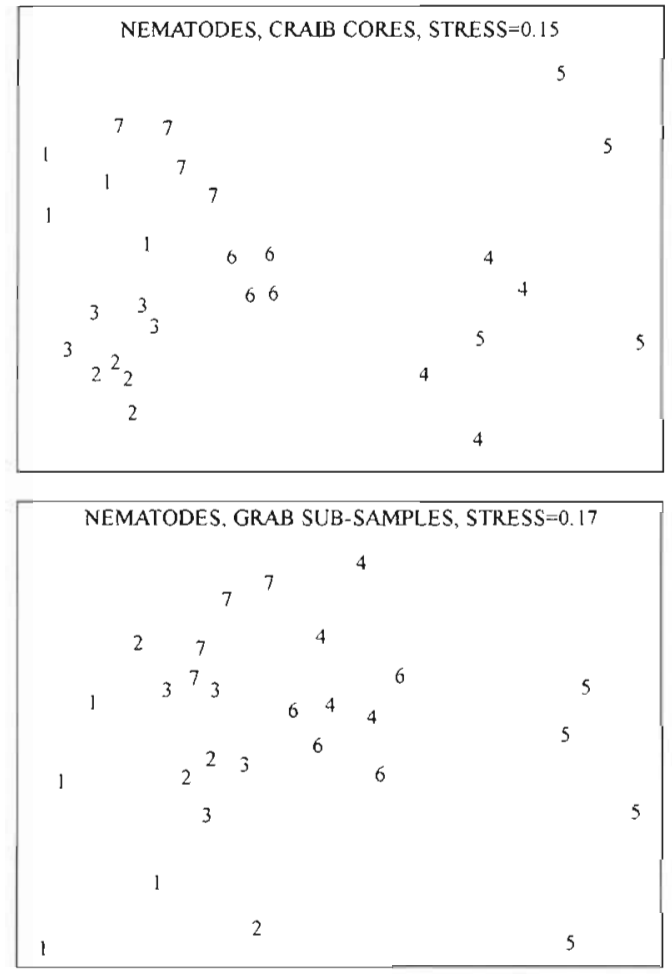

Fig. 6. Multidimensional scaling ordinations for fourth-root transformed nematode abundances from Craib core samples and subsamples from Day grabs

(Fig. 6), and differences between all stations are significant, except 3 and 2, and 3 and 7 (Table 2).

Ordination of fouth-root transformed copepod abundance data (Fig. 7) does not show a very clear pattern of impact, and ANOSIM supports this (Table 2). Ordination of fouth-root transformed macrofauna data does show a clear pattern, in that Stns 4 and 5, within the disposal site, are clearly separated from Stns 2, 3,6 and 7 (Fig. 7). Stn 1 clusters separately, suggesting that this site is also subject to some other environmental difference. ANOSIM separates all stations except 3 and 2 , and 3 and 6 (Table 2).

Similarity matrices, constructed from averaged transformed biotic data, were compared with each other. The results (Table 3) show that not all the matrices are significantly correlated $(p<0.05)$. Correlations between matrices derived from nematode and copepod abundances in Craib cores and macrofauna in Day grab samples are all significant. Matrices derived from nematode abundances in subsamples from Day grabs are not significantly correlated with those derived from abundances of other components of the benthos. The highest correlations are between nematodes from Craib core samples and macrofauna from grab samples, showing that patterns in community structure revealed by nematode abundances in Craib cores match patterns in macrofaunal community structure in Day grab samples more closely than do patterns in nematode community structure derived from nematode abundances in subsamples from those same Day grab samples.

Similarities percentages analyses (SIMPER) of fourthroot transformed nematode and macrofauna abundances, and square-root transformed copepod abundances, were used to determine the contributions from individual species to the Bray-Curtis dissimilarities between stations. Variation in abundance of a range of nematode species common to both stations accounts for most of the pairwise dissimilarities between Stns 1, 2, 3 and 7. Species important in characterising communities outside the disposal site are Sabatieria celtica and Richtersia inaequalis, and to a lesser extent a number of species including Spirinia parasitifera and Metoncholaimus scanicus. Species characteristic of communities within the disposal site, at Stns 4 and 5, include Sabatieria punctata, Sabatieria breviseta and Daptonema tenuispiculum. The community at Stn 6 is characterised by both $S$. celtica and $S$. punctata, among other species. A similar pattern of contributions

Table 2. Results of pairwise tests from 1-way ANOSIM, significance (p) of differences in community structure between Stations 1 to 7. Nematode and macrofauna data fourth-root transformed, copepod data square-root transformed

\begin{tabular}{|c|c|c|c|c|c|c|}
\hline & 1 & 2 & 3 & 4 & 5 & 6 \\
\hline \multicolumn{7}{|c|}{ Nematodes, Craib cores } \\
\hline 2 & 0.03 & & & & & \\
\hline 3 & 0.03 & 0.11 & & & & \\
\hline 4 & 0.03 & 0.03 & 0.03 & & & \\
\hline 5 & 0.03 & 0.03 & 0.03 & 0.23 & & \\
\hline 6 & 0.03 & 0.03 & 0.03 & 0.03 & 0.03 & \\
\hline 7 & 0.03 & 0.03 & 0.03 & 0.03 & 0.03 & 0.03 \\
\hline \multicolumn{7}{|c|}{ Nematodes, Day grabs } \\
\hline 2 & 0.03 & & & & & \\
\hline 3 & 0.03 & 0.51 & & & & \\
\hline 4 & 0.03 & 0.03 & 0.03 & & & \\
\hline 5 & 0.03 & 0.03 & 0.03 & 0.03 & & \\
\hline 6 & 0.03 & 0.03 & 0.03 & 0.03 & 0.03 & \\
\hline 7 & 0.03 & 0.03 & 0.26 & 0.03 & 0.03 & 0.03 \\
\hline \multicolumn{7}{|c|}{ Copepods, Craib cores } \\
\hline 2 & 0.03 & & & & & \\
\hline 3 & 0.03 & 0.11 & & & & \\
\hline 4 & 0.51 & 0.03 & 0.03 & & & \\
\hline 5 & 0.14 & 0.03 & 0.03 & 0.49 & & \\
\hline 6 & 0.09 & 0.09 & 0.03 & 0.06 & 0.06 & \\
\hline 7 & 0.06 & 0.06 & 0.03 & 0.17 & 0.37 & 0.43 \\
\hline \multicolumn{7}{|c|}{ Macrofauna } \\
\hline 2 & 0.03 & & & & & \\
\hline 3 & 0.03 & 0.46 & & & & \\
\hline 4 & 0.03 & 0.03 & 0.03 & & & \\
\hline 5 & 0.03 & 0.03 & 0.03 & 0.03 & & \\
\hline 6 & 0.03 & 0.03 & 0.17 & 0.03 & 0.03 & \\
\hline 7 & 0.03 & 0.03 & 0.03 & 0.03 & 0.03 & 0.03 \\
\hline
\end{tabular}



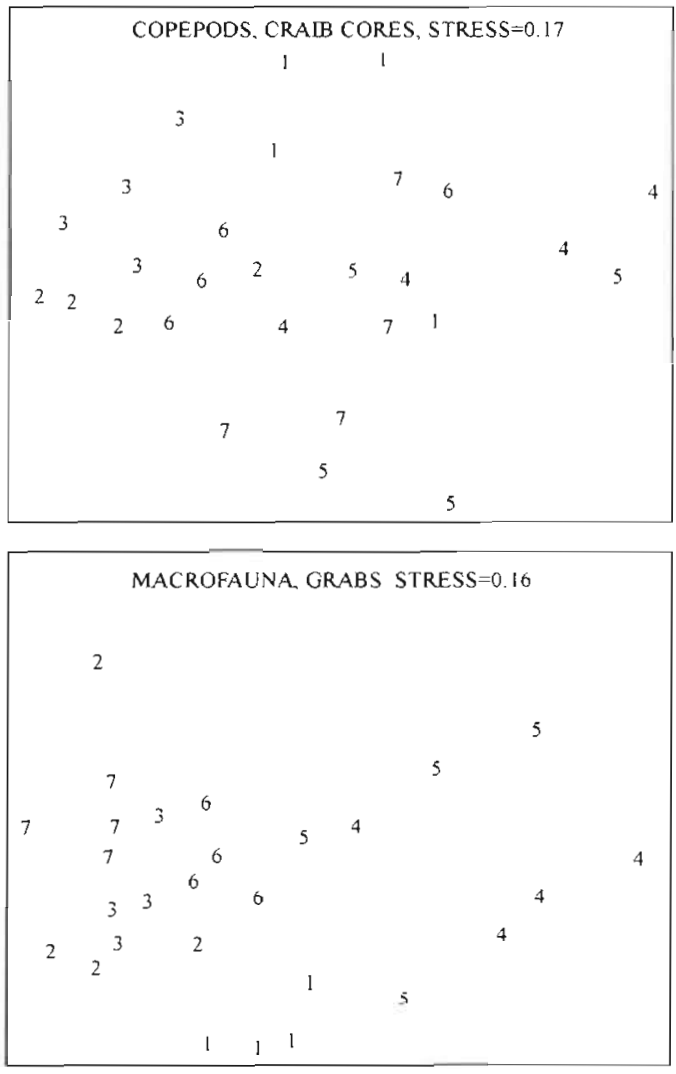

Fig. 7. Multidimensional scaling ordinations for square-root transformed copepod abundances from Craib core samples and fourth-root transformed macrofauna abundances from Day grabs

to dissimilarities between stations is evident in the nematode abundance data from grab subsamples.

The copepod community in these samples was surprisingly poor with only 22 species. The overall pattern of contributions from individual species is that a general decrease in numbers of individuals and species discriminates samples from within the disposal site from those without.

Many species contribute to differences in macrofaunal community structure between stations, but

Table 3. Pairwise Spearman rank correlations between similarity matrices derived from averaged transformed biotic abundance data. Nematode and macrofauna data fourth-root transformed, copepod data square-root transformed. " $p<0.05$ by a permutation test

\begin{tabular}{|lccc|}
\hline & $\begin{array}{c}\text { Nematodes } \\
\text { (Craibs) }\end{array}$ & $\begin{array}{c}\text { Nematodes } \\
\text { (grabs) }\end{array}$ & $\begin{array}{c}\text { Copepods } \\
\text { (Craibs) }\end{array}$ \\
\hline Nematodes (grabs) & 0.465 & & \\
Copepods (Craibs) & $0.606^{\circ}$ & 0.203 & \\
Macrofauna (grabs) & $0.668^{\circ}$ & 0.404 & $0.617^{\circ}$ \\
\hline
\end{tabular}

variation in the relative abundances of Lagis koreni (Polychaeta; Pectinariidae) and Mysella bidentata (Pelycypoda; Montacutidae) is important in characterising the macrofaunal community at each station. Stn 4 has high abundances of both species, as do Stns 5 and 1 to a lesser extent.

\section{Environmental variables}

Ordination by PCA (Fig. 8) of the environmental data (Table 4) shows that Stns 4 and 5 cluster separately from stations outside the disposal site, and also that Stn 1 is different from other stations. MDS ordinations of averaged abundances (Fig. 8) all indicate an impact at Stns 4 and 5. Correlations (Table 5) between the environmental and biotic matrices underlying the ordinations in Fig. 8 were significant $(p<0.01)$ between matrices derived from environmental data, nematode data from grab subsamples, and macrofauna, all samples taken from Day grabs. Whereas the correlation between nematode data from Craib cores and the environmental matrix was not significant $(p=0.09)$

Fig. 8. Ordination by PCA of environmental variables, and by MDS of averaged abundances from Stns 1 to 7. Environmental variables $\log (1+N)$ transformed nematodes and macrofauna fourthroot transformed, copepods square-root transformed
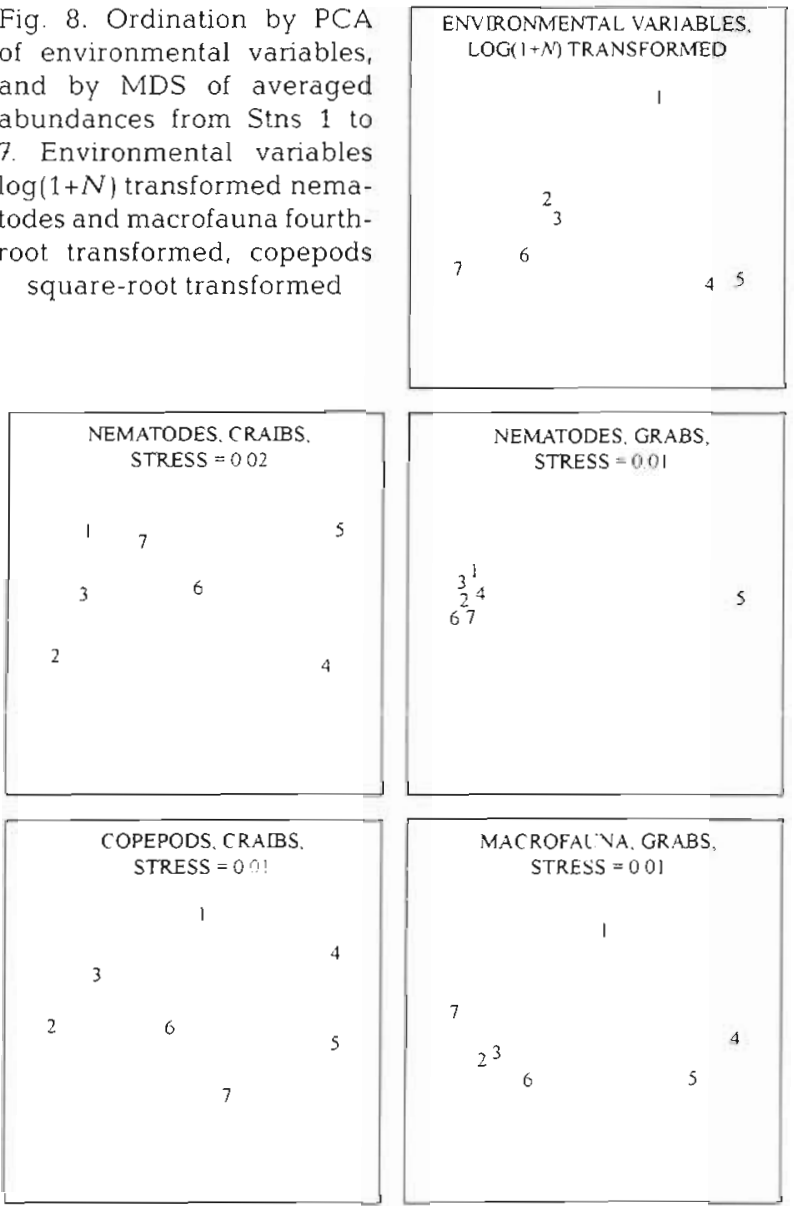
Table 4. Concentrations ( $\mu \mathrm{g} \mathrm{\textrm {g } ^ { - 1 }} \mathrm{dry}$ weight) of heavy metals and values of other environmental variables at Stns 1 to 7 . C\%: \% organic carbon; N\%: \% organic nitrogen; \% s/c: \% silt/clay

\begin{tabular}{|rrrrrrrrrrr|r|}
\hline Stn & $\mathrm{Cd}$ & $\mathrm{Cr}$ & $\mathrm{Cu}$ & $\mathrm{Hg}$ & $\mathrm{Ni}$ & $\mathrm{Pb}$ & $\mathrm{Zn}$ & $\mathrm{C} \%$ & $\mathrm{~N} \%$ & $\% \mathrm{~s} / \mathrm{C}$ \\
\hline 1 & 0.16 & 79 & 53 & 1.44 & 32 & 209 & 331 & 3.01 & 0.4 & 7.00 \\
2 & 0.26 & 69 & 45 & 1.25 & 30 & 103 & 171 & 2.45 & 0.27 & 6.07 \\
3 & 0.35 & 69 & 46 & 1.42 & 30 & 97 & 155 & 2.41 & 0.28 & 9.58 \\
4 & 0.65 & 94 & 74 & 2.62 & 30 & 136 & 372 & 2.58 & 0.27 & 33.39 \\
5 & 0.68 & 96 & 76 & 2.42 & 31 & 141 & 424 & 2.8 & 0.29 & 82.57 \\
6 & 0.40 & 66 & 43 & 1.47 & 26 & 90 & 163 & 2.16 & 0.25 & 8.11 \\
7 & 0.28 & 57 & 43 & 1.04 & 22 & 87 & 152 & 1.85 & 0.22 & 7.50 \\
\hline
\end{tabular}

the correlation between copepod data from Craib cores and the environmental matrix was marginally so $(\mathrm{p}=0.05)$.

In a standard product-moment correlation analysis, of all the measured environmental variables, only $\mathrm{Cr}$ and $\mathrm{Cu}$ are highly correlated ( $>0.95$ ). Thus all the variables were used in the BIO-ENV analyses, the results of which are summarised in Table 6. The highest correlation shown for the fourth-root transformed nematode abundance data from Craib core samples is 0.743 , with the variable \% silt/clay, indicating that of the environmental variables measured sediment composition, or some variable correlated with it, is most important in influencing changes in community structure at this site. Adding further variables degrades the correlation. Fourth-root transformed nematode abundance data from Day grab subsamples show a highest correlation of 0.779 , with a combination of 3 variables, $\%$ silt/clay, $\mathrm{Cd}$ and $\mathrm{Pb}$.

The results for square-root transformed copepod abundance data show a highest correlation value of 0.661 with 7 variables, $\mathrm{Cd}, \mathrm{Cr}, \mathrm{Cu}, \mathrm{Hg}, \mathrm{Ni}, \mathrm{Zn}$ and $\%$ silt/clay, but removal of different combinations of variables does not greatly degrade the correlation, suggesting that the relationships between copepod community structure and individual variables are generally weak. Fourth-root transformed macrofauna abundance data show high correlations with environmental variables, the highest being 0.935 with $\mathrm{Hg}$ and

Table 5. Spearman rank correlations $(\rho)$ between the Euclidean distance matrix derived from environmental variables $[\log (1+N)$ transformed] and similarity matrices derived from transformed biotic data. Nematode and macrofauna data fourth-root transformed, copepod data squareroot transformed

\begin{tabular}{|lcr|}
\hline & $p$ & \multicolumn{1}{c|}{$p$} \\
\hline Nematodes (Craibs) & 0.38 & 0.09 \\
Nematodes (grabs) & 0.59 & $<0.01$ \\
Copepods & 0.42 & 0.05 \\
Macrofauna & 0.77 & $<0.01$ \\
\hline
\end{tabular}

$\mathrm{Zn}$. Various other combinations of variables with $\mathrm{Hg}$ and $\mathrm{Zn}$ also give high correlations $(>0.9)$, suggesting that these metals are having an effect on macrofaunal community structure at this site. The fact that there were so few samples, only 7 , greatly reduces the power of all these techniques, and high correlations should be viewed with caution.

\section{DISCUSSION}

Whilst meiobenthic communities are sensitive to anthropogenic inputs to the marine environment (Coull \& Chandler 1992) it has long been recognised that the structure of the sediment is a major factor influencing meiobenthic community structure (Warwick \& Buchanan 1970, Heip et al. 1985, Coull 1988). Although the species assemblages in sandy and muddy substrata are usually different, there are no consistent differences in diversity in undisturbed habitats (Coull \& Fleeger 1977), indeed it has been suggested that comparable diversities can be anticipated in shallow sedimentary biotopes world-wide (Coull 1988). Change in sediment structure within an area may be expected to perturb meiobenthic community structure. At the Liverpool Bay dredgings disposal site, although nematode abundance in Craib core samples is not significantly reduced, there is a marked change in community structure at Stns 4 and 5, within the disposal site. The majority of univariate values are lower and the nematode community is more highly dominated and less diverse. The nematode community within the disposal site is dominated by species typical of muddier sediments such as Sabatieria punctata, $S$. breviseta and Daptonema tenuispiculum, rather than the sandy sediment species such as Rhabdodemania major, Richtersia inaequalis and $S$. celtica which are abundant outside the disposal site. Tietjen (1980), in a study of sublittoral nematode communities in the New York Bight (USA) apex found that the community of species in medium sands was sensitive to elevated loadings of metals and/or organic carbon, and that sufficiently high concentrations of these result in reductions in 
Table 6. Summary of results from BIO-ENV. Combinations of variables, $k$ at a time, giving the highest rank correlations between biotic and abiotic similarity matrices. Nematode and macrofauna fourth-root transformed, copepod data square-root transformed, abiotic variables $\log (1+N)$ transformed. Bold values: highest correlations. -: lower correlations omitted from the table; \% s/c: $\%$ silt/clay

\begin{tabular}{|c|c|c|c|c|c|}
\hline \multicolumn{2}{|l|}{$k$} & \multicolumn{2}{|c|}{ Best variable combinations } & & \\
\hline \multicolumn{6}{|c|}{ Nematodes, Craibs } \\
\hline 1 & $\begin{array}{l}\% \mathrm{~s} / \mathrm{c} \\
0.743\end{array}$ & $\begin{array}{l}\mathrm{Cd} \\
0.564\end{array}$ & $\begin{array}{l}\mathrm{Hg} \\
0.564\end{array}$ & - & \\
\hline 2 & $\begin{array}{l}\% \mathrm{~s} / \mathrm{c}, \mathrm{Cd} \\
0.617\end{array}$ & $\begin{array}{l}\% s / c, C u \\
0.562\end{array}$ & - & & \\
\hline 3 & $\begin{array}{l}\% \mathrm{~s} / \mathrm{c}, \mathrm{Cd}, \mathrm{Zn} \\
0.591\end{array}$ & - & & & \\
\hline \multicolumn{6}{|c|}{ Nematodes, grabs } \\
\hline 1 & $\begin{array}{l}\mathrm{Cd} \\
0.537\end{array}$ & $\begin{array}{l}\mathrm{Zn} \\
0.464\end{array}$ & - & & \\
\hline 2 & $\begin{array}{l}\% \mathrm{~s} / \mathrm{c}, \mathrm{Pb} \\
0.717\end{array}$ & $\begin{array}{l}\% \text { s/c, N\% } \\
0.663\end{array}$ & $\begin{array}{l}\% s / c_{,} c d \\
0.647\end{array}$ & - & \\
\hline 3 & $\begin{array}{l}\% \mathrm{~s} / \mathrm{c}, \mathrm{Cd}, \mathrm{Pb} \\
0.779\end{array}$ & $\begin{array}{l}\% \mathrm{~s} / \mathrm{c}, \mathrm{Cd}, \mathrm{N} \% \\
0.708\end{array}$ & $\begin{array}{l}\% \mathrm{~s} / \mathrm{c}, \mathrm{Cd}, \mathrm{Cu} \\
0.688\end{array}$ & $\begin{array}{l}\% \mathrm{~s} / \mathrm{c}, \mathrm{Zn}, \mathrm{N} \% \\
0.684\end{array}$ & - \\
\hline 4 & $\begin{array}{l}\% \mathrm{~s} / \mathrm{c}, \mathrm{Cd}, \mathrm{Pb}, \mathrm{Zn} \\
0.745\end{array}$ & $\begin{array}{l}\% \mathrm{~s} / \mathrm{c}, \mathrm{Cd}, \mathrm{Zn}, \mathrm{N} \% \\
0.716\end{array}$ & $\begin{array}{l}\% \mathrm{~s} / \mathrm{c}, \mathrm{Cd}, \mathrm{Cu}, \mathrm{Pb} \\
0.695\end{array}$ & - & \\
\hline \multicolumn{6}{|c|}{ Copepods, Craibs } \\
\hline 1 & $\begin{array}{l}\mathrm{Cr} \\
0.613\end{array}$ & $\begin{array}{l}\mathrm{Cu} \\
0.552\end{array}$ & - & & \\
\hline 2 & $\begin{array}{l}\mathrm{Cr}, \mathrm{Cu} \\
0.632\end{array}$ & $\begin{array}{l}\mathrm{Cr}, \mathrm{Hg} \\
0.607\end{array}$ & $\begin{array}{l}\mathrm{Hg}, \mathrm{Zn} \\
0.606\end{array}$ & - & \\
\hline 3 & $\begin{array}{l}\mathrm{Cd}, \mathrm{Cr}, \mathrm{Zn} \\
0.637\end{array}$ & $\begin{array}{l}\% \mathrm{~s} / \mathrm{C}, \mathrm{Ni}, \mathrm{Zn} \\
0.614\end{array}$ & $\begin{array}{l}\mathrm{Cr}, \mathrm{Cu}, \mathrm{Hg} \\
0.61\end{array}$ & - & \\
\hline 4 & $\begin{array}{l}\% \mathrm{~s} / \mathrm{c}, \mathrm{Hg}, \mathrm{Ni}, \mathrm{Zn} \\
0.653\end{array}$ & $\begin{array}{l}\% \mathrm{~s} / \mathrm{c}, \mathrm{Cu}, \mathrm{Ni}, \mathrm{Zn} \\
0.647\end{array}$ & $\begin{array}{l}\% \mathrm{~s} / \mathrm{c}, \mathrm{Cr}, \mathrm{Ni}, \mathrm{Zn} \\
0.636\end{array}$ & - & \\
\hline 7 & $\begin{array}{l}\mathrm{Cd}, \mathrm{Cr}, \mathrm{Cu}, \mathrm{Hg}, \mathrm{Ni}, \mathrm{Zn}, \% \mathrm{~s} / \mathrm{C} \\
0.661\end{array}$ & - & & & \\
\hline \multicolumn{6}{|c|}{ Macrofauna } \\
\hline 1 & $\begin{array}{l}\mathrm{Cd} \\
0.803\end{array}$ & $\begin{array}{l}\mathrm{Cu} \\
0.797\end{array}$ & $\begin{array}{l}\mathrm{Zn} \\
0.775\end{array}$ & - & \\
\hline 2 & $\begin{array}{l}\mathrm{Hg}, \mathrm{Zn} \\
0.935\end{array}$ & $\begin{array}{l}\mathrm{Hg}, \mathrm{Cu} \\
0.886\end{array}$ & $\begin{array}{l}\mathrm{Hg}, \mathrm{Cr} \\
0.864\end{array}$ & $\begin{array}{l}\mathrm{Cu}_{1} \mathrm{Cr} \\
0.863\end{array}$ & - \\
\hline 3 & $\begin{array}{l}\mathrm{Hg}, \mathrm{Cr}, \mathrm{Zn} \\
0.924\end{array}$ & $\begin{array}{l}\mathrm{Hg}, \mathrm{Cu}, \mathrm{Zn} \\
0.91\end{array}$ & $\begin{array}{l}\% \mathrm{~s} / \mathrm{C}_{1} \mathrm{Cr}, \mathrm{Zn} \\
0.895\end{array}$ & - & \\
\hline 4 & $\begin{array}{l}\mathrm{Cd}_{1} \mathrm{Cr}, \mathrm{Hg}, \mathrm{Zn} \\
0.921\end{array}$ & $\begin{array}{l}\% \mathrm{~s} / \mathrm{c}, \mathrm{Cr}, \mathrm{Hg}, \mathrm{Zn} \\
0.914\end{array}$ & $\begin{array}{l}\mathrm{Cr}_{1}, \mathrm{Cu}, \mathrm{Hg}, \mathrm{Zn} \\
0.912\end{array}$ & - & \\
\hline
\end{tabular}

abundances of species of Chromadoridae, Desmodoridae and Monoposthidae and increased abundances of species normally associated with finer sediments, especially Sabatieria pulchra (Comesomatidae). In our experience $S$. pulchra is an intertidal species, and other species of the $S$. pulchra group (Platt 1985) tend to occur in sublittoral situations (Platt \& Warwick 1988), but whichever species in the group it was, Tietjen's results closely complement the results of the present study.

The presence of dense aggregations of the large nematode Metoncholaimus scanicus (Oncholaimidae) at stations outside the disposal site may be evidence of disturbance resulting from the disposal of dredgings. Indicator species can be of 2 types (Moore \& Bett 1989). The first are those taxa which flourish in disturbed situations but which are rare elsewhere, such as large oncholaimid nematodes of the genus Pontonema which may become enormously abundant in sublittoral sediments under conditions of strong particulate organic enrichment. Metoncholaimus species are often abundant in situations where disturbance is not necessarily associated with organic enrichment. Although oncholaimids are large and have considerable buccal armature their trophic relationships are largely a matter for conjecture. Uptake of dissolved organic 
matter has been reported for 2 species of oncholaimid, Pontonema vulgare (Chia \& Warwick 1969) and Adoncholaimus thalassophygas (Lopez et al, 1979). For the latter species it was suggested that hatched juveniles derive nutrients primarily from dissolved organic matter released by microbial activity and that adults retain this ability but supplement their diet by scavenging and predation. It may be this ability that allows oncholaimids to thrive in disturbed and heavily enriched areas. The second type of indicator are species which are often common in unpolluted situations but which persist as dominants in species-poor, polluted meiofaunal communities. Species of the Sabatieria pulchra group appear to fit this category in sublittoral sands and sandy muds. As normal inhabitants of muds, where they tend to inhabit deeper layers, they are preadapted to survive decreased oxygen concentrations and high organic loadings and sulphide concentrations (Wieser \& Kanwisher 1961) and therefore to persist, even to thrive, under conditions normally restrictive for other nematodes, especially species that occur in well-oxygenated sands.

The copepod community throughout the transect is impoverished, and in some samples only the dominant species, Canuella perplexa, was present. This accounts, in the main, for the lack of sensitivity in analyses of these data, but even without showing a clear response patterns in copepod community structure are significantly correlated with those shown by other components of the benthos.

Analyses of macrofaunal abundance data indicate changes in community structure in response to dredgings disposal, but the response is more complex than that of the nematodes. High abundance $(A)$ and low diversity $\left(H^{\prime}\right)$ and evenness $(J)$ indicate a response at Stn 4 . High numbers of Lagis koreni, a species known to thrive in such conditions, are present. Low species numbers $(S)$ and richness $(d)$ also indicate a response at Stn 5. Multivariate analyses clearly separate both stations from the rest, but there is also evidence of an impact at Stn 1.

Deliberate corers, such as the Craib corer, are generally recommended for sublittoral meiofauna studies. The intercomparisons between the similarity matrices derived from the biotic abundance data are interesting in this respect. Significant relationships in community structure were found between meiofauna, both nematodes and copepods, collected by means of the Craib corer, and macrofauna collected using a Day grab, but not between meiofauna collected by subsampling from the Day grab and other components of the benthos. This implies that the method of sampling alters the perceived pattern of impact, and therefore using an appropriate sampling device is important in studies concerned with the details of benthic community struc- ture. Conversely, of all the components of the benthos sampled, only those sampled by Day grab showed significant correlations with the overall pattern in environmental variables, derived from surface scrapes also taken from Day grabs. It may be that both of these findings result from some bias resulting from the mechanics of the Day grab, such as a failure of the grab to adequately sample the surface layer of the sediment. The fact that there was only 1 environmental sample from each station, and that the biotic data were averaged, reduces the power of these techniques, and high correlations should be viewed with caution, though the striking similarity of the corresponding MDS plots (Fig. 8 ) is a reassuring safeguard that there are real links here to interpret. Taking subsamples from grab samples, however, presents practical advantages to many scientists concerned with monitoring discharges to the marine environment. Grabs are widely available, generally reliable, and personnel are familiar with their use. Although $H^{\prime}$ and $J$ did not vary significantly, non-parametric multivariate analyses of nematode abundance data from Day grab subsamples in this study indicated a response to dredgings disposal, but restricted to Stn 5 . Thus it may be possible, in surveys where the goal is simply to detect a response without examining in too much detail the nature of that response, to obtain useful results using a less appropriate sampler. It should also be borne in mind, however, that these samples were collected in shallow water and calm conditions, conditions which should favour grab sampling

Multivariate analyses of changes in community structure of the components of the benthos indicate that they are all affected by the disposal of dredged material, but different components of the benthos appear to be affected by dredgings disposal at this site in different ways. Changes in nematode community structure in Craib cores are not closely correlated with the overall pattern of measured environmental variables, but are related to changes in sediment composition or with some factor highly correlated with this. Other factors, such as physical disturbance, are extremely difficult to quantify, but changes in nematode community structure are restricted to stations within the disposal site, suggesting that the observed response is linked to the ongoing disposal of dredgings. Analysis of the measured environmental variables suggests that some sort of pollution event had impacted Stn 1 at some time, as concentrations of some metals were relatively high, although the \% silt/clay in the sediment was not, and a response to this was evident in analyses of the macrofauna data. Thus this study lends weight to the view that, owing to their relative longevity, effects of previous events may be visible in macrofauna community structure for some 
time, and that macrofauna and meiofauna thus provide different but complementary types of information, indicating that both should be used in marine pollution monitoring programmes (Heip 1992).

Acknowledgements. This work was funded by the UK Ministry of Agriculture, Fisheries and Food as part of an evaluation of the use of meiofauna in pollution monitoring programmes (project no. AE0210). We acknowledge D. Limpenny for assistance with sampling, M. A. Pendle for identifying the macrofauna, J. M. Gee for identifying the copepods and B. R. Jones for chemical analyses.

\section{LITERATURE CITED}

Chia FS, Warwick RM (1969) Assimilation of labelled glucose from seawater by marine nematodes. Nature 224:720-721

Clarke KR (1993) Non-parametric multivariate analyses of changes in community structure. Aust J Ecol 18:117-143

Clarke KR, Ainsworth M (1993) A method of linking multivariate community structure to environmental variables. Mar Ecol Prog Ser 92:205-219

Clarke KR, Green RH (1988) Statistical design and analysis for a 'biological effects' study. Mar Ecol Prog Ser 46: $213-226$

Clarke KR, Warwick RM (1994a) Similarity-based testing for community pattern: the 2 -way layout with no replication. Mar Biol 118:167-176

Clarke KR, Warwick RM (1994b) Changes in marine communities: an approach to statistical analysis and interpretation. Plymouth Marine Laboratory, Plymouth

Clarke KR, Warwick RM, Brown BE (1993) An index showing breakdown of seriation, related to disturbance, in a coralreef assemblage. Mar Ecol Prog Ser 102:153-160

Coull BC $(1988\}$ Ecology of the marine meiofauna, In: Higgins RP. Thiel $\mathrm{H}$ (eds) Introduction to the study of meiofauna. Smithsonian Institution Press, Washington, DC, p $18-38$

Coull BC, Chandler GT (1992) Pollution and meiofauna: field, laboratory and mesocosm studies. Oceanogr mar Biol A Rev 30:191-271

This article was submitted to the editor
Coull BC, Fleeger JW (1977) Long-term temporal variation and community dynamics of meiobenthic copepods. Ecology $58: 1136-1143$

Heip C (1992) Benthic studies: summary and conclusions. Mar Ecol Prog Ser 91:265-268

Heip C, Vincx M, Vranken G (1985) The ecology of marine nematodes. Oceanogr mar Biol A Rev 23:399-489

Heip C, Warwick RM, Carr MR, Herman PMJ, Huys R Smol N, Van Holsbeke K (1988) Analysis of community attributes of the benthic meiofauna of Frierfjord/Langesundfjord. Mar Ecol Prog Ser 46:171-180

Kruskal JB, Wish M (1978) Multidimensional scaling. Sage Publications, Beverly Hills

Lopez G, Riemann F, Schrage M (1979) Feeding biology of the brackish water oncholaimid nematode Adoncholaimus thalassophygas. Mar Biol 54:311-318

Moore CG, Bett BJ (1989) The use of meiofauna in marine pollution impact assessment. Zool J Linn Soc 96:263-280

Platt HM (1985) The freeliving marine nematode genus Sabatieria (Nematoda: Comesomatidae). Taxonomic revision and pictorial keys. Zool J Linn Soc 83:27-78

Platt HM, Warwick RM (1988) Freeliving marine nematodes. Part II. British Chromadorids. Synopses of the British fauna (New Series) No. 38, E. J. Brill/W. Backhuys, Leiden

Rees HL, Rowlatt SM, Limpenny DS, Rees EIS, Rolfe MS (1992) Benthic studies at dredged material disposal sites in Liverpool Bay. Aquat Environ Monit Rep Dir Fish Res GB 28: $1-21$

Rowlatt SM, Rees HL, Rees EIS (1986) Changes in sediments following the disposal of dredged materials in Liverpool Bay. CM ICES 1986/E: $1-1.8$

Tietjen JH (1980) Population structure and species distribution of the free-living nematodes inhabiting sands of the New York Bight apex. Estuar coast mar Sci 10:61-73

Warwick RM (1993) Environmental impact studies on marine communites: pragmatical considerations. Aust J Ecol 18: $63-80$

Warwick RM, Buchanan JB (1970) The meiofauna off the coast of Northumberland. I. The structure of the nematode population. J mar biol Ass UK 50:129-146

Wieser W, Kanwisher J (1961) Ecological and physiological studies on marine nematodes from a small salt marsh near Wood's Hole, Massachusetts. Limnol Oceanogr 3:262-270

Manuscript first received: March 8, 1995

Revised version accepted: June 6, 1995 